\title{
Thyroid Gland Lymphoma
}

National Cancer Institute

\section{Source}

National Cancer Institute. Thyroid Gland Lymphoma. NCI Thesaurus. Code C5265.

A lymphoma primarily involving the thyroid gland. The vast majority of cases are B-cell

non-Hodgkin lymphomas. Hodgkin lymphomas involving the thyroid gland are

exceedingly rare. 